\title{
Monsanto's Bollgard potentially compromised in India
}

A fresh controversy has erupted over Bacillus thuringiensis $(B t)$ cotton after the publication of a study by a government institute in India showing that Bt cotton planted in India is not as efficient in killing bollworms (Helicoverpa armigera) there as it is in the US or China. That's because it is not designed for India's longer ripening season. The findings have subsequently been exploited by a nongovernmental organization (NGO), which has alleged that US seed company Monsanto of St Louis, Missouri, exported to India a technology primarily suited for Western markets and not for Indian farmers. Their charge-not entirely denied by Monsanto-raises concerns that bollworm resistance to Bt cotton could emerge in the country.

The finding by the Central Institute of Cotton Research (CICR) in Nagpur published in Current Science (89, 291-298 (2005)) last July has embarrassed the Genetic Engineering 을 Approval Committee (GEAC), India's apex regulatory body. The study that triggered the controversy, led by Keshav Kranthi, showed that $B t$ hybrids commercially grown in India express less than the critical levels of the CrylAc Bt toxin required for full protection against bollworms late in the season. The toxin expression varied from hybrid to hybrid and was higher in leaves than in boll rind, bud and flower. This type of protection works well against Heliothis virescens, or tobacco budworm, a major pest in the US that feeds on leaves, but doesn't work against $H$. armigera, the major pest in India, which feeds mostly on bolls.

Tony Shelton, entomology professor at Cornell University in New York, is not surprised at Kranthi's conclusions. "It is already well documented that CrylAc cotton in general is not a consistent high dose-expressing plant for Helicoverpa," he points out. He adds, "the lack of a high dose [of the toxin] (in late season) will increase the likelihood of resistance development."

To remedy these potential problems, Kranthi suggests in his publication "India should focus on developing transgenic cotton varieties with tissue-specific promoters to enhance the expression of toxin genes in fruiting parts." $\mathrm{He}$ also writes that seed companies should evaluate their hybrids critically for the highest levels of expression in fruiting parts and also for a relatively effective level of toxin expression late in the season.

After the publication of this study, Gene Campaign, a New Delhi-based NGO, has demanded an inquiry to examine whether both Monsanto and GEAC have misled Indian

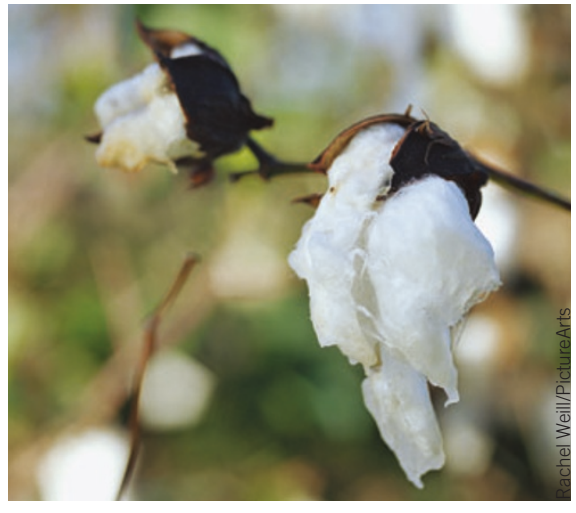

Controversy has erupted in India over the quality of imported Bt cotton seeds, which are deemed inappropriate for India's long ripening season.

farmers - the former by exporting the wrong technology and the latter for approving 13 new $B t$ hybrids this year ignoring the findings of CICR. The GEAC held two meetings on August 10 and September 16 to discuss the implications of the study but has withheld comments.

Monsanto's Graham Head, who is responsible for global coordination of insect resistance management, says this drop in protection is linked to a long ripening season for cotton in India-an issue that also crops up in Australia. It apparently causes no problem for farmers in the US where the ripening season is shorter (Nat. Biotechnol. 21, 958-959, 2003). "But it is an issue for Indian farmers who prefer to grow mediumto-long duration hybrids for their big boll size and superior fiber properties," argues Suman Sahai, president of Gene Campaign. Monsanto claims they have ongoing research efforts to improve each new variety of $B t$ and take into account late-season problems.

Kranthi also suggests that part of the problem has to do with the cultivation of hybrids in India, which are used instead of true varieties grown in the US, Australia and China. For instance, $\sim 25 \%$ of the seeds from hybrid bolls grown in India do not express the CrylAc, whereas all seeds in true varieties contain the toxin. "A global analysis on the comparative performance indicates that $B t$-cotton varieties appear to be more effective in controlling the Helicoverpa species compared to the hybrids being grown in India," Kranthi writes.

Gene Campaign's Sahai argues that Monsanto is promoting the use of hybrids in India to force farmers to buy fresh seeds every year even though it is aware that true varieties (whose seeds can be saved for subsequent crops) do better.
But Ranjana Smetacek, a Monsanto spokesperson in New Delhi says the choice of hybrids was purely circumstantial. "When we first considered taking our cotton traits to India, we found that most of the cotton seed companies that were capable of working with us to bring our traits to Indian farmers sold hybrids." She said that as a consequence, Monsanto decided to initially work with Mahyco, a major provider of hybrid seed in Jalna, and subsequently licensed its gene to a number of other hybrid seed companies. "Since that time, growers have adopted hybrid seed even more, so we believe that we made the correct decision."

But not everyone-including Kranthiagrees. In a lengthy article published on September 2 in the newspaper Hindu, he writes, "Indian researchers including our own group at CICR must intensify the efforts to develop $B t$ straight varieties for the use of Indian farmers." Ebrahimali Siddiq, former deputy chief of the Indian Council of Agricultural Research, doubts if companies will switch to true varieties because they have already spent a lot on hybrids. "One way to use hybrids and still avoid the problems found by Kranthi is to use parental lines each having a different $B t$ gene so that both genes are present in the hybrid," he comments. "I think there is plenty of scope for research here." According to Shelton, in Australia, dual $B t$ gene cotton has already replaced single $B t$ gene cotton.

As a result of the difference of efficacy of hybrids, Kranthi concludes, “ $B t$ cotton hybrids in India may therefore require more supplemental insecticide sprays than [are] being used on Bt-cotton varieties elsewhere in the world." Monsanto's Smetacek says the company has always warned "Bollgard cotton is not a panacea." Farmers are directed to scout their Bollgard fields for insects and supplement the protection by treating with an insecticide whose amount "varies from country to country," she remarks.

Entomologist Bruce Tabashnik of Arizona University cautions against such practice. Citing a recent Australian study, he says that decline in CrylAc concentration in Bt cotton late in the season causes nonrecessive inheritance of resistance in $H$. armigera. "Higher survival of cotton bollworm on $B t$ cotton will not necessarily speed its resistance to $B t$ cotton, particularly if survival of susceptible pests increases, as reported by Kranthi," says Tabashnik. But he fears "incomplete control of cotton bollworm by $B t$ cotton will not reduce insecticide use enough to avoid resistance to the sprayed insecticides."

K.S. Jayaraman, Hyderabad 